\title{
Tanaman Berkhasiat Obat dari Sub Kelas Sympetaleae yang digunakan Masyarakat
}

\author{
Almukarramah ${ }^{1}$ \\ Ibrahim $^{2}$ \\ Sufriadi $^{3}$ \\ ${ }^{\text {1-2 }}$ Pendidikan Biologi Univesitas Serambi Mekkah \\ almukarramah@serambimekkah.ac.id \\ ${ }^{3}$ Universitas Islam Ar-Raniry Aceh \\ sufriadi-2006@yahoo.co.id
}

\begin{abstract}
ABSTRAK
Tumbuhan ini sebagian besar tumbuh di perkarangan rumah atau kebun masyarakat di kawasan Pagar air Aceh Besar baik dibudidaya atau secara liar. Metode penelitian yang digunakan adalah metode deskriptif dengan lokasi penelitiannya adalah seluruh perkarangan rumah dan kebun yang terdapat di Gampong Tanjong Pagar Air Aceh Besar, Pengambilan data dengan cara observasi di lapangan dan mencatat jenis tanaman berkhasiat obat serta wawancara dengan ibu rumah tangga cara penggunaan sebagai obat. Hasil penelitian diperoleh 16 jenis tanaman dari sub kelas Sympetaleae yang terdapat di perkampungan dan bermanfaat sebagai obat, 10 jenis ditemukan banyak tumbuh di areal perkarangan rumah masyarkat sedangkan 6 jenis lagi tumbuh dikebun masyarakat atau sebagai bunga/hiasan rumah. Adapun organ tanaman yang banyak dipakai untuk obat berupa, akar, batang, daun, kulit, buah, herba, rimpang, biji, getah, atau umbi sekalipunt. Berbagai macam khasiat dari jenisjenis tanaman obat yang dijumpai dilokasi penelitian antara lain dapat menyembuhkan radang paru-paru, demam/ influenza, masuk angin, sebagai anti kanker, batuk rejan, bisul, radang saluran pernafasan, jerawat, batu saluran kencing, diare, rematik, tekanan darah tinggi, sakit perut, wasir, cacing keremi, beri-beri, sakit kunig, batuk berdahak, kudis, cacar air, radang tenggorokan, darah manis/gula, terlambat haid, ketombe, panu/kurap, asam lambung, diare dan meningkatkan nafsu makan serta penambah vitalitas untuk orang dewasa. Pada umumnya dapat digunakan oleh masyarakat tanpa efek samping dan biaya yang terjangkau kalangan warga miskin.
\end{abstract}

Kata Kunci : Tanaman Obat, Sympetalae

\section{PENDAHULUAN}

Letak geografis negara Indonesia yang kaya akan hutan tropis menutupi hampir seluruh daratan yang dilewati khatulistiwa, seluruh hutan tersebut menyelimuti sebagaian daerah tropic paru-paru dunia. Para pakar kebumian dan hutan bersepakat bahwa " bahwa hutan tropis Indonesia merupakan hutan alam tropis basah yang memiliki luas total hutan hampir 144 juta hektar atau berkisar $75 \%$ dari luas seluruh 
daratan" (Micell, 2016). Indonesia yang berada pada garis khatulistiwa dengan musim panas yang panjang, temperatur yang sempurna menjadikan Indonesia sebagai pusat keanekaragaman hayati, khususnya tumbuhan. Hal ini disebabkan Indonesia memiliki iklim tropis, dimana hujan merata sepanjang tahun dan sinar matahari yang melimpah setaip saat. Kondisi semacam ini menciptakan habitat yang ideal bagi hidupnya berbagai jenis tumbuhan. Ditinjau dari segi keanekaragaman tumbuhan, di Indonesia diperkirakan terdapat sekitar 25.000 jenis tumbuhan. Setengah dari jumlah ini diperkirakan mempunyai potensi untukk dimanfaatkan dan memberi nilai tambah bagi masyarakat (Ibrahim, Yahya \& Dzahir, 2018)

Dari hasil survey para mahasiswa IPB Bogor bahwa tercatat kurang lebih 30.000 jenis tanaman yang hidup di Indonesia, dengan kondisi anah yang subur dan iklim yang baik serta didukung oleh keanekaragaman flora membuat Indonesia menjadi salah satu negara penghasil komoditas obat-obatan yang potensial (Lestaridewi, N. K., \& Jamhari, 2017). Tiada kurang dari 1.000 jenis tanaman telah dimanfaatkan oleh masyarakat dalam upaya penyembuhan suatu penyakit, pencegah penyakit, peningkatan daya tahan tubuh, dan mengembalikan kesegaran tubuh. Dari sejumlah tanaman obat tersebut menurut Ditjen Pengawasan Obat dan Makanan, baru sebanyak 497 jenis tanaman yang sudah digunakan dalam industri obat tradisional yang banyak dikomsumsi penduduk Indonesia.

Tumbuhan tropis mengandung ratusan sampai ribuan komponen senyawa kimia. Senyawa kimia yang terkandung pada tumbuhan ada yang bersifat racun namun ada juga yang bersifat menyembuhkan sehingga digunakan sebagai obat" Pemanfaatan tumbuhan bermanfaat sebagai obat tradisional oleh masyarakat semakin hari semakit meningkat, hal ini dikarenakan masyarakat semakin sadar akan pentingnya kembali kealam dengan memanfaatkan bahan alami atau dikenal dengan istilah back to nature dan seiring dengan berkembangnya ilmu pengetahuan tentang penggunaan tumbuhan sebagai obat tradisional serta semakin bermunculan industri yang menggunakan tumbuhan sebagai bahan baku industrinya menjadikan tumbuhan sebagai alternatif pengobatan yang dilakukan disamping pengobatan secara medis (Puspita, L., Swastini, D. A., \& Arisanti, 2013).

Dalam penelitian Hasanuddin (2017), bahwa nilai kesehatan adalah investasi penting dalam kehidupan manusia, tanpa kesehatan manusia tidak akan dapat memnuhi segala kebutuhannya karena masyarakat di tuntut berperan serta dalam pembangunan kesehatan. Upaa pengobatan alternative dengan obat-obatan tradionala merupakan bentuk peran serta masyarakat dalam menunjang pembangunan kesehatan"

Pakar obat tradisional, Mursito ( 2016), bahwa tanaman-tanaman obat ini dapat ditemukan di daerah-daerah sekitar kita misalnya tumbuh secara liar dihutan, dipinggir sungai, disekitar perkarangan rumah, dipinggir jalan ataupun yang tumbuh sebagai gulma. Tanaman obat merupakan warisan nenek moyang serta telah menjadi obat tradisional yang dikenal oleh masyarakat Indonesia secara turun-temurun yang berupa jamu dan Simplisia." Symplisia adalah bahan dari tanaman masih sangat sederhana, murni belum tercampur atau belum diolah tetapi sudah dalam keadaan bersih dan dikeringkan "Tumbuan biji merupkan golongan tumbuhan dengan tingkat 
Almukarramah, Ibrahim, Sufriadi

perkembangan filogenetik tertinggi, dengan ciri khasnya ialah adanya suatu organ yang berupa biji" (Krismawati, A., \& Sabran, 2017)

Unit dari tumbuhan biji secara klasik dibedakan dalam dua anak devisi yaitu: Tumbuhan biji terbuka (Gymnospermae) dan tumbuhan biji tertutup (Angiospermae). Kedua anak devisi itu dibedakan satu dengan yang lain berdasarkan ciri-ciri seperti : habitat, akar, batang, daun, bunga, dan juga cara penyerbukkannya. Kemudian Gembong $\mathrm{Tj}$ (2004) jenis tumbuhan Sympetaleae merupakan salah satu sub kelas Dikotyledoneae dengan ciri utama dari tumbuhan ini yaitu adanya bunga dengan hiasan yang lengkap yang terdiri dari kelopak dan mahkota dengan daun-daun mahkota ang berdekatan menjadi satu. Sympetaleae diklasifikasikan menjadi beberapa bangsa namun dengan cirri utama yang dimilikinya membuat tumbuhan ini lebih mudah untuk diamati, Adanya pengklasifikasikan tumbuhan ini merupakan faktor yang sangat menguntungkan bagi upaya penelitian maupun pemanfaatan tanaman baik untuk penenalan tumbuhan itu sendiri maupun pemanfaatannya yang dapat digunakan untuk pengobatan serta pengembangan formulasi berbagai ramuan yang berasal dari tanaman. Namun terkadang pengetahuan tentag tanaman obat ini masih kurang diketahui jenis dan manfaatnya oleh masyarakat pada umumnya.

Dari hasil penelitian Muhlisah (2017), Ada jenis -jenis tamaman yang berkhasiat obat yang dapat digunakan masyarakat ternyata sangat banyak. Kita sangat beruntung karena banyak jenis tanaman obat yang dapat tumbuh dengan baik di sekitar rumah sebagai, tanaman obat tersebut ada yang berupa rempah-rempah, tanaman buah, tanaman hias, tanaman sayur, bahkan tanaman liar sekalipun..

Dari sub kelas Sympetaleae diantaranya seperti Mengkudu (Morinda Citrifolia L.) dari suku Rubiaceae Beluntas (Plucea indica), Sembung ( Blumea balsamifera), Tapak liman (Elephantos scaber) dari suku Asteraceae / Compositae, dan Tapak dara (Vinca rosea) dari suku Apocynacea sudah banyak dikenal dan dirasakan manfaatnya oleh masyarakat sebagai tumbuhan obat tradisional, namun masih banyak lagi tumbuhan dari sub kelas ini yang lain memiliki keindahan karena hiasan bunganya berkhasiat obat yang dapat kita budidayakan untuk kita ambil manfaatnya.

Kawasan Gampong Tanjong Pagar Air Aceh Besar banyak ditemukan berbagai jenis tanaman yang tumbuh baik secara alami ataupun karena penanaman langsung oleh masyarakat/budidaya (Widowati, T., Bustanussalam, Sukiman, H., \& Simanjuntak, 2016). Dari bermacam jenis tumbuhan yang terdapat didalamnya ada yang sebagian jenis sudah diketahui manfaatnya namun banyak pula dari jenis-jenis tumbuhan yang terdapat masih kurang diketahui manfaatnya terutama tanaman tanaman dari kelas Sympetaleae ini. Berdasarkan permasalahan di atas perlu dilakukan suatu penelitian untuk memperoleh informasi mengenai “ Jenis - Jenis Tanaman Obat Dari Sub Kelas Sympetaleae yang Terdapat Gampong Tanjong Pagar Air Aceh Besar yang dapat digunakan warga sebagai obat tradisional dari sub Kelas Sympetaleae.

\section{METODE}

Data dikumpulkan dengan teknik observasi yaitu mengamati langsung ke lokasi penelitiandan juga proses Wawancara semi terstruktur dimana responden terdiri tokoh masyarakat dan ibu rumah tangga di Gampong Tanjong Aceh Besar yang sering menggunakan tanaman sebagai obat. Pada area pengambilan sampel tiap jenis dari 
tanaman dari sub kelas Sympetalae yang ditemukan dicatat dalam suatu tabel dan tanaman yang belum diketahui namanya dikoreksi sebagai bahan untuk diidentifikasi. Data yang dianalisis secara deskritif, yaitu setelah data terkumpul ditampilkan dalam bentuk tabel berdasarkan nama lokal, nama ilmiah, family, ordo/ bagian yang digunakan sebagai obat.

\section{HASIL DAN PEMBAHASAN}

Pada bagian ini diuraikan mengenai data penelitian yang dibahas sesuai dengan fakta atau kenyataan dilapangan. Untuk lebih jelasnya dari penelitian ini penulis akan menginformasikan hal-hal yang relevan dengan pembahasan hasil penelitian. Dalam penelitian ini menunjukkan bahwa secara keseluruhan terdapat 14 jenis tanaman sub kelas Sympetalae yang berkhasiat obat 9 jenis ditemukan di areal perkarangan rumah, sedangkan 5 jenis ditemukan I kebun masyarakat. Adapun jenis-jenis tanaman sub kelas Sympetalae tersebut dapat dilihat pada tabel berikut.

Tabel. 1. Jenis jenis Tanaman Obat yang ditemukan di Lokasi Penelitian

\begin{tabular}{|c|c|c|c|c|c|c|c|}
\hline \multirow[t]{2}{*}{ No } & \multirow[t]{2}{*}{ Nama Jenis } & \multirow[t]{2}{*}{ Nama Ilmiah } & \multirow[t]{2}{*}{ Famili } & \multicolumn{4}{|c|}{ Dusun } \\
\hline & & & & 1 & 2 & 3 & 4 \\
\hline 1 & Cabe Merah & Capsicum annum & Solonaceae & $\mathrm{v}$ & $\mathrm{v}$ & $\mathrm{V}$ & $\mathrm{V}$ \\
\hline 2 & Cabe rawit & Capsicum fustesce & Solonaceae & $\mathrm{V}$ & $\mathrm{V}$ & - & $\mathrm{V}$ \\
\hline 3 & Pare & $\begin{array}{l}\text { Momordica } \\
\text { charanthia L. }\end{array}$ & Cucurbitaceae & $\mathrm{V}$ & - & - & $\mathrm{V}$ \\
\hline 4 & Mengkudu & Morinda citrifolia & Rubiaceae & $\mathrm{v}$ & $\mathrm{v}$ & - & - \\
\hline 5 & Tapak dara & $\begin{array}{l}\text { Cathanrathus } \\
\text { roseus L. }\end{array}$ & Aocynaceae & - & $\mathrm{v}$ & $\mathrm{V}$ & $\mathrm{V}$ \\
\hline 6 & Mentimun & Cucumis sativus & Cucurbitaceae & $\mathrm{v}$ & - & - & $\mathrm{V}$ \\
\hline 7 & Tomat & $\begin{array}{l}\text { Solanum } \\
\text { lycopersicum }\end{array}$ & Solanaceae & $\mathrm{v}$ & $\mathrm{v}$ & - & - \\
\hline 8 & Terong & $\begin{array}{l}\text { Solanum } \\
\text { melongena }\end{array}$ & Solanaceae & $\mathrm{v}$ & - & - & $\mathrm{V}$ \\
\hline 9 & Kangkung & Ipomea aquatic & $\begin{array}{l}\text { Convolvulace } \\
\text { ae }\end{array}$ & - & - & - & $\mathrm{V}$ \\
\hline 10 & Melati & Jasminum sambac & Oleaceae & $\mathrm{V}$ & $\mathrm{v}$ & - & $\mathrm{v}$ \\
\hline 11 & Kaca piring & Gardenia augusta & Rubiaceae & $\mathrm{V}$ & - & $\mathrm{v}$ & - \\
\hline 12 & Tembelekan & Lantana camara & Vebernaceae & $\mathrm{v}$ & - & - & - \\
\hline 13 & Biduri & $\begin{array}{l}\text { Calostropis } \\
\text { gigentea }\end{array}$ & $\begin{array}{l}\text { Asclepiadacea } \\
\mathrm{e}\end{array}$ & $\mathrm{V}$ & $\mathrm{V}$ & - & $\mathrm{V}$ \\
\hline 14 & Pulai & Alstonia scholaris & Aocynaceae & $\mathrm{v}$ & $\mathrm{v}$ & - & - \\
\hline 15 & Ubi jalar & Ipomea batatas & Solanales & $\mathrm{v}$ & $\mathrm{v}$ & - & $\mathrm{v}$ \\
\hline 16 & Labu air & Legenaria sicerria & Cucurbitaceae & $\mathrm{V}$ & $\mathrm{V}$ & - & - \\
\hline
\end{tabular}

Sumber data : Tanaman Gampong Tanjong Aceh Besar 
Almukarramah, Ibrahim, Sufriadi

Berdasarkan tabel diatas bahwa ada jenis tanaman sub kelas Sympetalae berkhasiat obat yang ditemukan di perkarangan rumahwarga seperti tanaman pare, bunga melati, kaca piring, tembelekan,pulai, mengkudu, cabe merah, cabe rawit kecil, dan tapak dara, sedangkan jenis yang ditemukan dikebun dari jenis seperti tomat, ubi jalar, terong biduri, kangkung darat, mentimun dan labu air (Dewi, I, Astuti, K. W., \& Warditiani, 2013).

\section{Khasiat dan cara Pemakaian sebagai Obat keluarga.}

Bagian tumbuhan yang dimanfaatkan oleh masyarakat sebagai obat adalah berua akar, batang, daun dan buah. Dalam membuat ramuan dari tumbuhan tersebut sebagian ada yang digunakan secara tunggal tanpa dicampur dengan tumbuhan lainnya, sedangkan lainnya atau dengan rempah-rempah seperti kencur, kunyit, jahe, dan temulawak.

Tabel Nama Tanaman dan cara prosesnya

\begin{tabular}{|c|c|c|c|c|c|}
\hline $\begin{array}{l}\text { No } \\
.\end{array}$ & $\begin{array}{l}\text { Nama } \\
\text { Ilmiah }\end{array}$ & $\begin{array}{l}\text { Nama } \\
\text { Specis }\end{array}$ & $\begin{array}{l}\text { Organ } \\
\text { nya }\end{array}$ & $\begin{array}{l}\text { Khasiat sebagai } \\
\text { obat }\end{array}$ & Cara Penggunaan \\
\hline 1 & $\begin{array}{l}\text { Capsicum } \\
\text { annum }\end{array}$ & $\begin{array}{l}\text { Cabe } \\
\text { Merah }\end{array}$ & $\begin{array}{l}\text { Buah, } \\
\text { dan daun }\end{array}$ & $\begin{array}{lr}\text { Khasiatnya } & \text { dapat } \\
\text { menyembuhkan } & \text { rematik, } \\
\text { sariawan,sakit } & \text { gigi, } \\
\text { influenza, } & \text { dan } \\
\text { meningkatkan } & \text { nafsu } \\
\text { makan } & \end{array}$ & $\begin{array}{l}\text { Dapat dikonsumsi dalam } \\
\text { campuran makanan sehari- } \\
\text { hari, dan bisa juga } 10 \mathrm{~g} \\
\text { serbuk cabai diseduh dengan } \\
1 / 2 \text { gelas panas dan diaduk } \\
\text { sampai bercampur rata. } \\
\text { Daunnya dapat dilumatkan } \\
\text { untuk mengobati panas }\end{array}$ \\
\hline 2. & $\begin{array}{l}\text { Capsicum } \\
\text { fustesce }\end{array}$ & $\begin{array}{l}\text { Cabe } \\
\text { rawit }\end{array}$ & Buah & $\begin{array}{l}\text { Menyembuhkan migrain, } \\
\text { menormalkan kembali } \\
\text { kaki dan tangan yang } \\
\text { lemas, batuk berdahak, } \\
\text { dan menambah nafsu } \\
\text { makan }\end{array}$ & $\begin{array}{l}\text { Dapat dikonsumsi dalam } \\
\text { campuran makanan sehari- } \\
\text { hari }\end{array}$ \\
\hline 3. & $\begin{array}{l}\text { Momordica } \\
\text { Charantia L. }\end{array}$ & Pare & Buah & $\begin{array}{l}\text { Mengobati demam, sakit } \\
\text { perut, disentri, radang } \\
\text { mata, bisulan, cacingan, } \\
\text { meningkatkan nafsu } \\
\text { makan, menguatkan daya } \\
\text { tahan tubuh bagi enderita } \\
\text { diabetes }\end{array}$ & $\begin{array}{l}\text { Buahnya dapat direbus dan } \\
\text { diseduh airnya untuk } \\
\text { diminum atau dimasak } \\
\text { sebagai sayur-sayuran. } \\
\text { Sedangkan bagian daunnya } \\
\text { dijemur hingga kering lalu } \\
\text { ditumbuk menjafi bubuk dan } \\
\text { dioelskan pada bagian tubh } \\
\text { luar yang sakit }\end{array}$ \\
\hline 4 & $\begin{array}{l}\text { Morinda } \\
\text { citrifolia L. }\end{array}$ & $\begin{array}{l}\text { Mengku } \\
\text { du }\end{array}$ & $\begin{array}{l}\text { Akar, } \\
\text { daun, } \\
\text { buah, } \\
\text { kulit } \\
\text { batang } \\
\text { dan } \\
\text { bunga }\end{array}$ & $\begin{array}{l}\text { Meningkatkan kekuatan } \\
\text { tulang, membersihkan } \\
\text { darah, peluruh kencing, } \\
\text { peluruh haid, pelembut } \\
\text { kulit, obat batuk, obat } \\
\text { cacing, pencahar, anti } \\
\text { septic, dan meningkatkan } \\
\text { sirkulasi dan }\end{array}$ & $\begin{array}{l}\text { Buahnya dapat dikonsumsi } \\
\text { langsung. Sedangkan } \\
\text { daunnya dilumatkan dalam } \\
\text { bentuk ramuan sehingga } \\
\text { mudah untuk diminum }\end{array}$ \\
\hline
\end{tabular}




\begin{tabular}{|c|c|c|c|c|c|}
\hline & & & & menghilangkan ketombe & \\
\hline 5. & $\begin{array}{l}\text { Cathanranth } \\
\text { u roseus } \mathrm{L} \text {. }\end{array}$ & $\begin{array}{l}\text { Tapak } \\
\text { dara }\end{array}$ & $\begin{array}{l}\text { Seluruh } \\
\text { tanaman }\end{array}$ & $\begin{array}{l}\text { Sebagai anti kangker, } \\
\text { mempelancar kencing, } \\
\text { mengobati tekanan darah } \\
\text { mengobati tekanan darah } \\
\text { tinggi, menghetika } \\
\text { pendarahan, menurunkan } \\
\text { panas badan dan peluruh } \\
\text { haid }\end{array}$ & $\begin{array}{l}\text { Daunnya direbus kemudian } \\
\text { air rebusannya diminum. }\end{array}$ \\
\hline 6. & $\begin{array}{l}\text { Curcumis } \\
\text { sativus }\end{array}$ & $\begin{array}{l}\text { Mentim } \\
\text { un }\end{array}$ & $\begin{array}{l}\text { Daun dan } \\
\text { buah }\end{array}$ & $\begin{array}{l}\text { Obat disentri,diare pada } \\
\text { anak kecil, tekanan darah } \\
\text { tiggi, dan radang kulit } \\
\text { bernanah }\end{array}$ & $\begin{array}{l}\text { Buahnya dapat dikonsumsi } \\
\text { langsung sebagai sayur atau } \\
\text { buah sedangkan daunnya } \\
\text { dapat dibuat jus dan diberi } \\
\text { sedikit tambahan gula pasir }\end{array}$ \\
\hline 7. & $\begin{array}{l}\text { Solanum } \\
\text { lycopersicu } \\
\mathrm{m}\end{array}$ & Tomat & $\begin{array}{l}\text { Seluruh } \\
\text { tanaman }\end{array}$ & $\begin{array}{l}\text { Mengobati diabetes, gusi } \\
\text { berdarah, bisul dimulut, } \\
\text { bisul di perut, dan kulit } \\
\text { bengkak akibat } \\
\text { keracunan. Tomat juga } \\
\text { banyak mengandung } \\
\text { vitamin A, B1, dan C }\end{array}$ & $\begin{array}{l}\text { Buahnya dapat langsung } \\
\text { sebagai lalap, dijus dengan } \\
\text { menggunakan sedikit gula } \\
\text { dan dimasak bersama sayur- } \\
\text { sayuran. Sedangkan batang } \\
\text { dan daunnya direbus dalam } \\
\text { air hingga mendidih } \\
\text { kemudian air rebusannya } \\
\text { dapat digunakan untuk } \\
\text { mencuci bagian yang sakit }\end{array}$ \\
\hline 8. & $\begin{array}{l}\text { Solanum } \\
\text { melongena }\end{array}$ & Terong & $\begin{array}{l}\text { Seluruh } \\
\text { tanaman }\end{array}$ & $\begin{array}{l}\text { Berak darah, } \begin{array}{r}\text { batuk } \\
\text { rematik dan radang } \\
\text { sendi, }\end{array} \\
\text { tenggorokan kronis, luka } \\
\text { gigitan ular, luka } \\
\text { bengkak karena infeksi, } \\
\text { gatal -gatal karena alergi } \\
\text { cuaca }\end{array}$ & $\begin{array}{l}\text { Buahnya dapat direbus dan } \\
\text { sedikit gula merah dan } \\
\text { diminum. Atau dapat pula } \\
\text { merebus akar dan gula } \\
\text { secukupnya menjadi sirup. } \\
\text { Sedangkan } \\
\text { untuk pengobatan luar } \\
\text { seluruh bagian tanaman } \\
\text { terong drebus kemudian air } \\
\text { rebusannya digunakan untuk } \\
\text { mencuci atau dibasuhkan ke } \\
\text { bagian yang sakit. }\end{array}$ \\
\hline 9. & $\begin{array}{l}\text { Pomea } \\
\text { aquatica }\end{array}$ & $\begin{array}{l}\text { Kangku } \\
\text { ng }\end{array}$ & $\begin{array}{l}\text { Daun dan } \\
\text { batang }\end{array}$ & $\begin{array}{l}\text { Mengobati gatal, kapalan } \\
\text { (penebalan kulit), } \\
\text { bengkak akibat sengatan } \\
\text { lipan, mimisan, sakit } \\
\text { gigi, susah kencing, } \\
\text { wasir, dan pendarahan } \\
\text { pada urin dan kotoran }\end{array}$ & $\begin{array}{l}\text { Untuk pengobatan dalam } \\
\text { kangkung dapat direbus dan } \\
\text { ditambah dengan gula, } \\
\text { garam dan cuka. Sedangkan } \\
\text { untuk pengobatan bagian } \\
\text { luar kangkung dan } \\
\text { campurannya dilumatkan } \\
\text { dan dioleskan ke bagian } \\
\text { yang sakit }\end{array}$ \\
\hline 10 & $\begin{array}{l}\text { Jasminu } \\
\text { sambac }\end{array}$ & Melati & $\begin{array}{l}\text { Daun dan } \\
\text { bunga }\end{array}$ & $\begin{array}{l}\text { Mengobati sakit mata, } \\
\text { bengkak akibat } \\
\text { senggatan lebah, demam, } \\
\text { sakit kepala,sesak nafas, } \\
\text { dan jerawat }\end{array}$ & $\begin{array}{l}\text { Daun dan bunganya dapat } \\
\text { dlumatkan dan ditempelkan } \\
\text { pada beberapa bagian tubuh } \\
\text { yang sakit atau dalam mata }\end{array}$ \\
\hline 11. & $\begin{array}{l}\text { Gardenia } \\
\text { augusta }\end{array}$ & $\begin{array}{l}\text { Kaca } \\
\text { piring }\end{array}$ & $\begin{array}{l}\text { Akar, } \\
\text { daun dan }\end{array}$ & $\begin{array}{l}\text { Menyembuhkan demam } \\
\text { susah buang air kecil, }\end{array}$ & $\begin{array}{lrr}\text { Dilumatkan } & \text { dan } \\
\text { ditempelkan pada } & \text { bagian }\end{array}$ \\
\hline
\end{tabular}


Almukarramah, Ibrahim, Sufriadi

\begin{tabular}{|c|c|c|c|c|c|}
\hline & & & bunga & $\begin{array}{l}\text { muntah-muntah dan } \\
\text { sariawan }\end{array}$ & $\begin{array}{l}\text { yang sakit, untuk } \\
\text { pengobatan dalam dapat } \\
\text { direbus dan diminum airnya }\end{array}$ \\
\hline 12. & $\begin{array}{l}\text { Lantana } \\
\text { camara }\end{array}$ & $\begin{array}{l}\text { Tembele } \\
\text { kan }\end{array}$ & Daun & Mengobati bengkak & $\begin{array}{llr}\text { Dilumatkan } & & \text { dan } \\
\text { ditempelkan } & \text { pada } & \text { bagian } \\
\text { yang sakit } & & \end{array}$ \\
\hline 13. & $\begin{array}{l}\text { Calastropis } \\
\text { gigentea }\end{array}$ & Biduri & Daun & $\begin{array}{l}\text { Menyembuhkan borok } \\
\text { kronis gigita ular bercun, } \\
\text { pegal linu, perut terasa } \\
\text { penuh, dan kecing nanah }\end{array}$ & $\begin{array}{l}\text { Dilumatkan dan } \\
\text { ditempelkan ke bagian yang } \\
\text { luka atau sakit }\end{array}$ \\
\hline 14. & $\begin{array}{l}\text { Alstonia } \\
\text { scholaris }\end{array}$ & Pulai & $\begin{array}{l}\text { Kulit } \\
\text { batang }\end{array}$ & $\begin{array}{l}\text { Mengobati tekanan darah } \\
\text { tinggi, demam perut } \\
\text { kembung dan penambah } \\
\text { daya }\end{array}$ & $\begin{array}{l}\text { Kulit batangnya direbus dan } \\
\text { air rebusannya dapat sebagai } \\
\text { ramuan }\end{array}$ \\
\hline 15. & $\begin{array}{l}\text { Ipomea } \\
\text { batatas }\end{array}$ & Ubi jalar & Umbi & $\begin{array}{l}\text { Mengobati fruktasi } \\
\text { tulang, rapuh tulang }\end{array}$ & $\begin{array}{lll}\text { Buah ubi } & \text { jalar di rebus } \\
\text { dimakan } & \text { secara } & \text { teratur } \\
\text { sehari 3x } & & \\
\end{array}$ \\
\hline 16. & $\begin{array}{l}\text { Legenaria } \\
\text { sicerria }\end{array}$ & Labu air & $\begin{array}{l}\text { Daun } \\
\text { Pucuk } \\
\text { dan tunas } \\
\text { batang }\end{array}$ & $\begin{array}{l}\text { Mengobati tekanan darah } \\
\text { tinggi, atau } \\
\text { pembengkakan liver }\end{array}$ & $\begin{array}{l}\text { Pucuk, daun dan buah } \\
\text { direbus setengah matang, } \\
\text { diminum airnya } \\
\text { hangat }\end{array}$ \\
\hline
\end{tabular}

Tanaman sub kelas Sympetalea yang tertera pada tabel di atas dimanfaatkan dalam mengobati penyakit bagian luar tubuh atau bahagian dalam diracik dengan cara dilumatkan, ditumbuk, atau diremas-remas kemudian baru ditempelkan dan dibalurkan pada bagian tubuh yang sakit. Sedangkan untuk penyakit bagian dalam tubuh pada umumnya diracik dengan cara direbus dahulu, kemudian air rebusannya diminum sesuai dengan dosis yang diperlukan, namun ada juga yang dapat dikonsumsi secara langsung atau saat tanaman itu diambil dari pohonnya.

\section{PENUTUP}

Tanaman sub kelas Sympetalea yang ada di sekitar perumahan masyarakat Gampong Tangjong Pagar air dapat menjadi obat atas bermacam jenis penyakit. Umunnya masyarakat Gampong tanjong menggunakan jenis tanaman dari sub kelas Sympetalea untuk mengobati penyakit luar tubuh seperti kangkung, kaca piring, melati, tembelekan, biduri, cabe rawit, cabe merah, dan mengkudu selain itu masyarakat juga menggunakan beberapa jenis tanaman Sympetalae tersebut untuk mengobati penyakit bagian dalam tubuh seperti cabe merah, cabe rawit, mentimun, labu air, ketela, mengkudu, pare, tapak dara, pulai, kaca piring, kangkung dan terong berduri. Perlu dilatih anggota keluarga untuk menanam, bididaya, dan cara-cara pengolahan untuk obat keluarga.

\section{Daftar Pustaka}

Dewi, I, Astuti, K. W., \& Warditiani, N. K. (2013). Identifikasi Kandungan Kimia Ekstrak Kulit Buah Manggis (Garcinia mangostana L .). Jurnal Farmasi Fakultas Matematika Dan Ilmu Pengetahuan Alam Universitas Uadaya. https://doi.org/10.1016/j.ijpara.2010.12.001 
Gembong Tjiptrosupomo (2004). Taksonomi Tumbuhan ( Spermathophyt). Gadjha Mada Universitas Press. Yogyakarta.

Ibrahim,Yahya \& Muhamad (2018). Pendekatan Science teknology dan Society dalam pembelajaran. Yayasan Pintar. Jakarta.

Muhlisah F. (2017). Sayur Dan Bumbu Dapur Berkhasiat Obat. Penerbar Swadaya Jakarta.

Mursito, B (2016). Ramuan Tradisional Untuk Penyakit Malaria, Penebar Swadaya; Jakarta.

Krismawati, A., \& Sabran, M. (2017). Pengelolaan Sumber Daya Genetik Tanaman Obat Spesifik Kalimantan Tengah. Buletin Plasma Nutfah. https://doi.org/10.21082/blpn.v12n1.2006.p16-23

Lestari, P., Farmasi Yayasan Tenaga Pembangunan Arjuna, A., \& Samosir, T. (2016). Studi Tanaman Khas Sumatera Utara Yang Berkhasiat Obat. Jurnal Farmanesia.

Lestaridewi, N. K., \& Jamhari, M. (2017). Kajian Pemanfaatan Tanaman Sebagai Obat Tradisional Di Desa Tolai Kecamatan Torue Kabupaten Parigi Moutong. E-Jip Biol.

Puspita, L., Swastini, D. A., \& Arisanti, C. I. A. (2013). Skrining Fitokimia Ekstrak Etanol 95\% Kulit Buah Manggis (Garcinia mangostana L .). Jurnal Farmasi Udayana. https://doi.org/2301-7716

Widowati, T., Bustanussalam, Sukiman, H., \& Simanjuntak, P. (2016). Isolasi dan Identifikasi Kapang Endofit dari Tanaman Kunyit ( Curcuma longa L .) sebagai Penghasil Antioksidan. Biopropal Industri. https://doi.org/10.1057/978113728. 